\title{
Community Empowerment Strategy in Handling Efforts of Stunting in Malutu Village, Hulu Sungai Selatan
}

\author{
Nizma A Hamdie", Andi Tenri Sompa, Muhammad Anshar Nur
}

Masters in Development Administration, Postgraduate Program, Lambung Mangkurat University, Jl. Brigjen H. Hasan Basri, Pangeran, Kec. Banjarmasin Utara, Kota Banjarmasin, Kalimantan Selatan 70123, Indonesia

\author{
DOI: $10.36348 /$ sjef.2020.v04i09.004 \\ | Received: 22.08.2020 | Accepted: 31.08.2020 | Published: 09.09.2020 \\ *Corresponding author: Nizma A Hamdie
}

\section{Abstract}

This study aims to determine how the role of human development cadres (KPM) in handling stunting and community empowerment strategies in handling stunting in Malutu Village. The method used in this research is a combination research that combines quantitative methods and qualitative methods to be used together in a research activity, so that more comprehensive, valid, reliable and objective data are obtained. Data were collected by interview, area mapping and documentation. Interviews were conducted with key figures, namely the Head of Malutu Village, Posyandu Cadres, Human Development Cadres and Village Empowerment Assistants. The results showed that the problems faced by Human Development Cadres in handling stunting in Malutu Village were that the function of cadres was not optimal, the capacity building given their time was still limited so that field supplies were not sufficient and there was no further training and lack of public awareness about the dangers of stunting. The strategy in community empowerment programs in an effort to deal with stunting in Malutu Village is the strategy of SO or strength and opportunity. SO strategy is a strategy that is determined to get optimal effort. After knowing and taking advantage of the strengths, we can take full advantage of the opportunities that exist. Community empowerment strategies that can be carried out are using the available budget for optimal stunting management, increasing the capacity of human resources through support from the Hulu Sungai Selatan District Government and establishing communication between actors and making joint work plans in handling stunting.

Keywords: Strategy, community empowerment, stunting, human development cadres.

Copyright @ 2020: This is an open-access article distributed under the terms of the Creative Commons Attribution license which permits unrestricted use, distribution, and reproduction in any medium for non-commercial use (NonCommercial, or CC-BY-NC) provided the original author and source are credited.

\section{INTRODUCTION}

In the Presidential Regulation of the Republic of Indonesia Number 59 of 2017 concerning the implementation of achieving the goals of sustainable development in the second global goal, namely eliminating hunger, achieving food security and good nutrition, and increasing sustainable agriculture and in the second target by 2030, eliminating all forms of malnutrition, including by 2025 achieve the internationally agreed target for short and thin children under the age of five, and meet the nutritional needs of adolescent girls, pregnant and nursing mothers, and the elderly. However, in reality the government still has homework to achieve development goals, where there are still high cases of malnutrition.

Malnutrition is often assumed to be the result of food insecurity, even though it is not the only or not the main cause of malnutrition, except that under conditions of hunger, other factors such as maternal knowledge, parenting, access to health services, water and sanitation have important role. Misperceptions in society make this problem difficult to reduce and require great efforts from the government and various related sectors. Stunting is a chronic nutritional problem caused by insufficient nutritional intake for a long time, generally due to food intake that does not meet nutritional needs. Stunting occurs starting from the womb and only appears when the child is two years old. Stunting has long-term effects, in the form of reduced cognitive abilities and physical development, and reduced health capacity. In addition, stunting poses a risk of death in children, and affects the functional and physical aspects of the child's body. So that stunting in adulthood has important consequences in terms of body size, work performance and reproduction and the risk of chronic disease $[1,2]$. Conditions that influence the factors causing stunting include, among others, the political and economic conditions of the local area, 
educational status, community culture, food systems, water conditions, sanitation and the environment.

Stunting conditions in Hulu Sungai Selatan in 2018 the prevalence of stunting decreased to $35.06 \%$ compared to five years ago in 2013 which was at $49.9 \%$. Even though the prevalence has decreased, the local government of Hulu Sungai Selatan Regency is still committed to reducing it again according to the targets of the South Kalimantan and National Governments. (www.kesmas.kemkes.go.id - Basic Health Research/Riskesdas 2018). One of the government's efforts in handling stunting in the village is by selecting a Human Development Cadre or abbreviated as KPM whose duties and functions are as cadres that facilitate the handling of stunting convergence. KPM, together with other community empowerment activists, facilitate and advocate for an increase in village budget expenditures, primarily sourced from the Village Fund, to be used to finance stunting prevention activities in accordance with the needs and conditions of the Village. With regard to the explanation above, the researchers made an article based on the results of research related to the role of human development cadres (KPM) in implementing stunting management as well as community empowerment strategies in handling stunting in Malutu Village. It is hoped that this article can describe the role of the human development cadre (KPM) and serve as a basis for making policies to deal with stunting in Malutu Village.

\section{RESEARCH METHODS}

This study uses a combination research method. A combination research method is a research method that combines quantitative methods and qualitative methods used together in a research activity, so that more comprehensive, valid, reliable and objective data are obtained. The focus of combining the two methods (qualitative and quantitative) is more on data collection techniques and data analysis, so that researchers can compare all the data findings from the two methods, which will then obtain mutually reinforcing conclusions and suggestions.

The research location was chosen based on the number of people with the highest number of stunting patients who were located in Malutu Village, Padang Batung District, Hulu Sungai Selatan Regency, amounting to 14 people. Field research to thesis preparation is planned to be carried out from February to June 2020. Primary data for stunting children were obtained from children who actively attended two Posyandu (Integrated Healthcare Center) in Malutu Village, namely Posyandu Goa Berangin and Posyandu Sedap Malam. The research focuses more on children who are indicated by existing stunting. Respondents who were targeted for interviews were Posyandu cadres, community development cadres, village empowerment assistants and the village head of Malutu.
Secondary data were taken from village profiles to conduct area mapping and recapitulation data on the number of stunting children at Puskesmas Padang Batung.

The data analysis technique used by the researcher is by doing three ways, namely (1) interview technique which is the process of collecting data by asking questions to sources to be answered orally, assisted by an interview guide that contains a list of strategic issues formulated in the SWOT analysis can be used as a guide for informants in answering questions. This is done by means of questions and answers with people who are considered to have an interest and have knowledge and experience. (2) Mapping or mapping of the area to obtain information covering physical facilities and social conditions by describing the condition of the surrounding area in general and comprehensive. (3) Documentation is a study technique used in order to collect secondary data that can be used as information in the form of letters, regulations, decisions or other relevant archives, in accordance with the research to be carried out. The analysis used in this study was a SWOT analysis to determine what kind of community empowerment strategy was used to handle stunting in Malutu Village. The analysis phase begins by formulating factors related to internal and external factors in the form of strengths, weaknesses, opportunities and threats that will be obtained using a SWOT analysis. The decision-making process in determining the right strategy, of course, requires an objective analysis of internal or external conditions, this analysis will be obtained from the results of the assessment in interviews with the respondents who have been determined. The results of the assessment of internal and external conditions will produce a group of factors, namely; strength, weakness, opportunity, threat. Then from the group of factors obtained, an analysis will be carried out, namely a SWOT matrix analysis, by conducting a merger interaction (merger) of the internal factor group (strength, weakness), with the group of external factors (opportunity, threat). The results of the SWOT analysis will be compared with the results of interviews with several predetermined sources, mapping of areas and transects or direct observation, where the results of this analysis will obtain several alternative strategies for handling stunting.

\section{RESULTS AND DISCUSSION}

Malutu Village is one of the villages in Padang Batung District, Hulu Sungai Selatan Regency, which is $7 \mathrm{Km}$ from the District capital and $14 \mathrm{Km}$ from the Regency capital, consisting of 4 RT and 2 RW. Based on village administrative data, the total population of the population is 503 heads of families or 1,490 people, consisting of 737 men and 753 women. The majority of the population of Malutu Village have a profession as farmers and have an average education of only elementary school. Malutu Village has health facilities and infrastructure as in Table-1. 
Table-1: Public Health Facilities and Infrastructure in Malutu Village

\begin{tabular}{|l|l|l|}
\hline No. & Facilities and infrastructure & Total \\
\hline 1. & Public toilet & 10 \\
\hline 2. & Integrated Healthcare Center & 2 \\
\hline 3. & Maternity Hospital & 1 \\
\hline 4. & Supporting Puskesmas & 1 \\
\hline 5. & Midwife & 1 \\
\hline 6. & Nurse & 1 \\
\hline 7. & Trained TBAs & 1 \\
\hline 8. & Active Posyandu cadres & 12 \\
\hline
\end{tabular}

Fulfilling the need for clean water in Malutu Village, the majority of the population still draws from river water sources, as shown in Table-2.

Table-2: Provision of Clean Water Needs in Malutu Village

\begin{tabular}{|l|l|l|}
\hline No. & Source of Clean Water Needs & Number of households \\
\hline 1. & Dug well & 2 \\
\hline 2. & PDAM (Regional Drinking Water Company) & 0 \\
\hline 3. & Rainwater Collector & 0 \\
\hline 4. & Pump Well & 0 \\
\hline 5. & Tap Water Piping & 0 \\
\hline 6. & General Hydrant & 10 \\
\hline 7. & River water & 400 \\
\hline 8. & Embung (retention basin) & 46 \\
\hline 9. & Water springs & 0 \\
\hline
\end{tabular}

Source: Malutu Village Profile Data 2019

Based on basic data on stunting in Hulu Sungai Selatan District, the low coverage of households using proper drinking water sources in Malutu Village is one of the causes of stunting. In general, the factors that influence stunting are maternal and child health (KIA), nutrition counseling, hygiene, parental care, drinking water and sanitation, early childhood education (PAUD), social protection and food security. The conditions of stunting children in Malutu Village can be seen in Table- 3 and Table-4 below:

Table-3: Stunting children data at Posyandu Goa Berangin, Malutu Village

\begin{tabular}{|l|l|l|l|l|l|l|l|}
\hline No & Name & Age (month) & Gender & Weight & Height & Z-Score & Height/Age \\
\hline 1 & DM & 53 & P & 11.5 & 95 & -2.35 & Short \\
\hline 2 & AA & 52 & L & 11.6 & 92 & -3.16 & Very short \\
\hline 3 & MHH & 43 & L & 15.8 & 92 & -2.1 & Short \\
\hline 4 & P & 40 & P & 10 & 89 & -2.17 & Short \\
\hline 5 & A & 32 & P & 8.8 & 80 & -3.29 & Very short \\
\hline 6 & KR & 20 & P & 6.5 & 68 & -4.9 & Very short \\
\hline 7 & RA & 20 & P & 8.5 & 76 & -2.23 & Short \\
\hline 8 & MKA & 23 & L & 7.3 & 72 & -5 & Very short \\
\hline 9 & NA & 13 & P & 7.5 & 69 & -2.38 & Short \\
\hline 10 & MR & 59 & L & 9.6 & 86 & -5.08 & Very short \\
\hline 11 & MR & 31 & P & 9.7 & 83 & -2.3 & Short \\
\hline
\end{tabular}

Data source: Padang Batung Subdistrict Health Center, December 2019

Table-4: Stunting children data at the Sedap Malam Posyandu, Malutu Village

\begin{tabular}{|l|l|l|l|l|l|l|l|}
\hline No & Name & Age (month) & Gender & Weight & Height & Z-Score & Height/Age \\
\hline 1 & YH & 59 & P & 12.6 & 98 & $-2,3$ & Short \\
\hline 2 & HM & 49 & P & 9.8 & 87 & $-3,7$ & Very short \\
\hline 3 & MN & 32 & L & 9.1 & 84 & $-2,6$ & Short \\
\hline
\end{tabular}

Data source: Padang Batung Subdistrict Health Center, December 2019

The standard of body length according to age for boys and girls aged 0-60 months based on the
Minister of Health regulation number 2 of 2020 can be seen in Table-5 and Table-6. 
Table-5: Standard Body Length by Age (PB / U) for Boys aged 0 to 60 Months

\begin{tabular}{|l|l|l|l|l|l|l|l|}
\hline \multirow{2}{*}{ Age (month) } & \multicolumn{1}{|c|}{ Body Length (cm) } \\
\cline { 2 - 8 } & $\mathbf{- 3 ~ S D}$ & $\mathbf{- 2 ~ S D}$ & $\mathbf{- 1 ~ S D}$ & Median & +1 SD & +2 SD & +3 SD \\
\hline 23 & 78.0 & 81.0 & 83.9 & 86.9 & 89.9 & 92.9 & 95.9 \\
\hline 32 & 82.8 & 86.4 & 89.9 & 93.4 & 96.9 & 100.4 & 103.9 \\
\hline 43 & 88.4 & 92.4 & 96.4 & 100.4 & 104.5 & 108.5 & 112.5 \\
\hline 52 & 92.5 & 96.9 & 101.2 & 105.6 & 109.9 & 114.2 & 118.6 \\
\hline 59 & 95.6 & 100.2 & 104.8 & 109.4 & 114.0 & 118.6 & 123.2 \\
\hline
\end{tabular}

Table-6: Standard Body Length by Age (PB / U) for Girls aged 0 to 60 months

\begin{tabular}{|l|l|l|l|l|l|l|l|}
\hline \multirow{2}{*}{$\begin{array}{l}\text { Age } \\
\text { (month) }\end{array}$} & \multicolumn{6}{|l|}{ Body Length (cm) } \\
\cline { 2 - 8 } & -3 SD & -2 SD & -1 SD & Median & +1 SD & +2 SD & +3 SD \\
\hline 13 & 67.3 & 70.0 & 72.6 & 75.2 & 77.8 & 80.5 & 83.1 \\
\hline 20 & 73.7 & 76.7 & 79.9 & 82.7 & 85.7 & 88.7 & 91.7 \\
\hline 31 & 80.7 & 84.3 & 87.9 & 91.4 & 95.0 & 98.6 & 102.2 \\
\hline 32 & 81.3 & 84.9 & 88.6 & 92.2 & 95.8 & 99.4 & 103.1 \\
\hline 40 & 85.8 & 89.8 & 93.8 & 97.7 & 101.7 & 105.7 & 109.7 \\
\hline 49 & 90.3 & 94.6 & 99.0 & 103.3 & 107.7 & 112.0 & 116.4 \\
\hline 53 & 92.1 & 96.6 & 101.1 & 105.6 & 110.1 & 114.6 & 119.1 \\
\hline 59 & 94.7 & 99.5 & 104.2 & 108.9 & 113.6 & 118.3 & 123.1 \\
\hline
\end{tabular}

Source: Permenkes Number 2 Year 2020

In general, the Z-Score calculation is:

$Z$-Score $=\frac{\text { Individual Value of Subject }- \text { Reference Standard Value }}{\text { Reference Standard Intersection Value }}$ Reference Standard Intersection Value

Where the individual subject value is obtained from the measurement of the child's height or body length. The reference standard value and the reference standard deviation value are taken from the table of body length standards according to age (PB / U) of boys and girls aged 0 to 60 months who are in attachment to Regulation of the Minister of Health of the Republic of Indonesia Number 2 of 2020 regarding anthropometric standards for children. The condition of children who are stunted is 14 (fourteen), consisting of 8 (eight) short people and 6 (six) very short children. The condition of these children is only based on height, where the height or length of the body divided by the age index does not meet WHO standards. Meanwhile, related to the mental development of stunting children is still not visible.

\section{Problems in Handling Stunting}

Malutu Village has selected and appointed a Human Development Cadre (KPM) through a Village Head Decree. This KPM has been given capacity building by elements of the Health Office, the Village Community Empowerment Service, the Food Security Service and Village Community Empowerment Experts in the Village Community Empowerment Assistance Program. The goal of stunting management carried out by the Human Development Cadre aims to reduce the prevalence rate of stunting in Malutu Village. Activities in this empowerment program are not limited to assisting in posyandu activities but also raising awareness about the meaning of stunting. However, in reality, the role of KPM every month is only providing assistance in posyandu activities in the village. This shows that the role of KPM is still not optimally implemented.

The Revised Village Expenditure Budget that has been allocated in the 2019 fiscal year is Rp.15,000,000 (fifteen million rupiah) for several activities in the efforts to deal with stunting. Meanwhile, in the 2020 fiscal year, Rp. 5,500,000 (five million five rarus thousand rupiah) for handling stunting in Malutu Village.

In general, the implementation of empowerment carried out by KPM as a responsibility to the people of Malutu Village, does not always run smoothly, this is because there are several problems that sometimes become an inhibiting factor in the implementation of these program activities. Based on the results of the interviews conducted, several KPM problems in implementing the empowerment program for handling stunting, namely the not optimal function of KPM, this can be seen in the absence of a follow-up work plan for KPM in the stunting management program. Another problem is that the training provided is limited in time and there is no simulation for some of the related materials. This causes the level of understanding of the material presented to be less than optimal. The absence of further capacity building is also a problem in itself. After going to the community to carry out their functions, it turns out that the field has encountered several difficulties, so this further capacity building is very important to discuss together and find solutions. In addition, the lack of public awareness about the dangers of stunting is also a challenge. 
Based on the description above, it can be concluded that the problems faced in the handling of stunting in Malutu Village are the number of assistants who are still lacking, training or capacity building of actors is still lacking, public awareness about stunting is still lacking and supporting advice is still not optimal.

\section{Community Empowerment Strategies in Handling Stunting}

Determining the right strategy in the implementation of empowerment including the empowerment program for handling stunting in Malutu Village is an important factor in the success of the program. One method for determining the strategy is using a SWOT analysis. SWOT analysis is a way of analyzing internal and external factors as a strategic step in a more profitable business optimization. Analysis of the internal (IFAS) and external (EFAS) factors of the community empowerment program in an effort to deal with stunting in Malutu Village, can be seen in Table-7 below:

Table-7: Analysis of Internal (IFAS) and External (EFAS) Factors for Community Empowerment Programs in Stunting Management Efforts

\begin{tabular}{|c|c|c|c|c|}
\hline No & Description & Weight & Skor & $\begin{array}{l}\text { Value } \\
\text { (Weight } \\
\text { x Score) }\end{array}$ \\
\hline \multirow[t]{4}{*}{$\mathrm{I}$} & Strength & 100 & & 375 \\
\hline & a. The budget can be allocated from the APBDesa & 45 & 4 & 180 \\
\hline & b. Availability of human resources who can act as assistants in the village & 30 & 4 & 120 \\
\hline & c. Communication between actors in the village can run well & 25 & 3 & 75 \\
\hline \multirow[t]{4}{*}{ II } & Weaknesses & 100 & & 340 \\
\hline & a. KPM capacity is not optimal & 40 & 4 & 160 \\
\hline & b. There is no work plan for activities yet & 35 & 3 & 105 \\
\hline & c. The budget has not been optimally absorbed & 25 & 3 & 75 \\
\hline \multirow[t]{4}{*}{ III } & Opportunities & 100 & & 345 \\
\hline & a. District government support is very good & 45 & 4 & 180 \\
\hline & $\begin{array}{l}\text { b. Because stunting is a national issue, many parties can help when the } \\
\text { work plan is in place. }\end{array}$ & 35 & 3 & 105 \\
\hline & c. Human resources involved are not only from the village & 20 & 3 & 60 \\
\hline \multirow[t]{4}{*}{ IV } & Threat & 100 & & 340 \\
\hline & a. Public understanding of stunting is still low & 30 & 3 & 90 \\
\hline & b. Don't feel that handling stunting is a shared responsibility & 40 & 4 & 160 \\
\hline & c. The perception in society that stunting is not dangerous & 30 & 3 & 90 \\
\hline
\end{tabular}

Based on the data above, it can be seen that the highest value is from internal factors, namely strength with a value of 375 . The next step after analyzing internal factors and external factors is analyzing and choosing strategies as shown in the following figure.

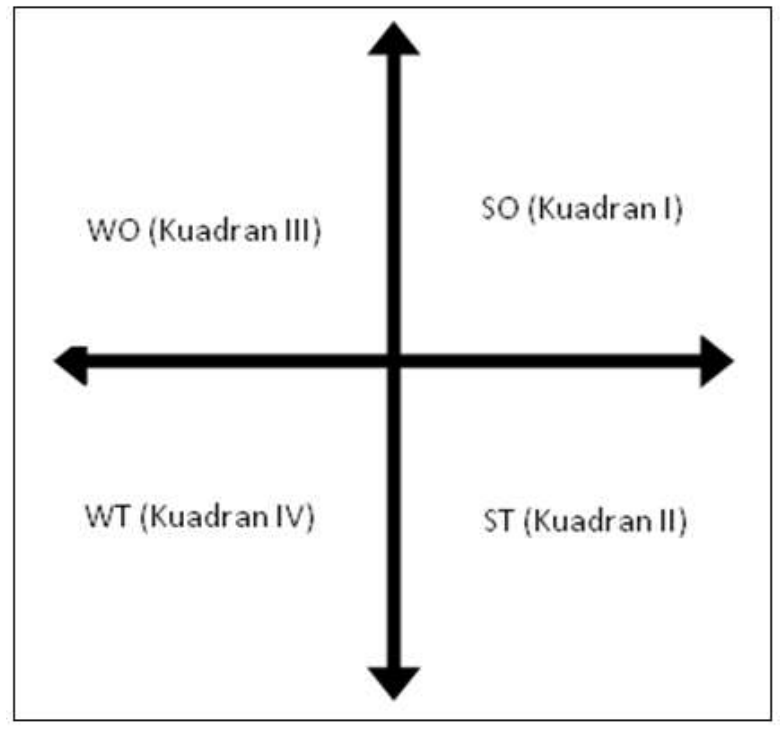

Fig-1: Analysis and Strategy Options 
From Figure-1 it can be seen that the position of the empowerment program in the effort to handle stunting in Malutu Village is in quadrant I, which means that the internal factors in this case are very good opportunities. The choice of strategy used is the SO strategy (quadrant I) which uses strength to take advantage of opportunities. Based on the IFAS and EFAS analysis, an alternative strategy for community empowerment was formulated using a SWOT matrix analysis, as presented in Table- 8 below:

Table-8: SWOT matrix

\begin{tabular}{|c|c|c|}
\hline Internal & $\begin{array}{l}\text { Strenghth } \\
\text { a. The budget can be allocated from the APBDes } \\
\text { b. Availability of human resources who can act } \\
\text { as assistants in the village } \\
\text { c. Communication between actors in the village } \\
\text { can run well }\end{array}$ & $\begin{array}{l}\text { Weakness } \\
\text { a. KPM capacity is not optimal } \\
\text { b. There is no work plan for } \\
\text { activities yet } \\
\text { c. The budget has not been } \\
\text { optimally absorbed }\end{array}$ \\
\hline $\begin{array}{l}\text { Oppurtunity } \\
\text { a. District government } \\
\text { support is very good } \\
\text { b. Since stunting is a } \\
\text { national issue, many } \\
\text { parties can help when the } \\
\text { work plan is in place. } \\
\text { c. Human resources } \\
\text { involved are not only } \\
\text { from the village }\end{array}$ & $\begin{array}{l}\text { SO Strategy } \\
\text { a. Using the available budget for optimal } \\
\text { stunting management } \\
\text { b. Increasing the capacity of human resources } \\
\text { can be through the support of the district } \\
\text { government }\end{array}$ & $\begin{array}{l}\text { WO Strategy } \\
\text { a. The capacity of KPM can be } \\
\text { increased with the support of } \\
\text { the district government so that } \\
\text { a work plan can be made. } \\
\text { b. Raising national issues as } \\
\text { material to make the public } \\
\text { aware of stunting and as a } \\
\text { basis for compiling a work } \\
\text { plan. }\end{array}$ \\
\hline $\begin{array}{l}\text { Threaths } \\
\text { a. Public understanding of } \\
\text { stunting is still low } \\
\text { b. Do not feel that handling } \\
\text { stunting is a shared } \\
\text { responsibility } \\
\text { c. The perception in society } \\
\text { that stunting is not } \\
\text { dangerous }\end{array}$ & $\begin{array}{l}\text { ST Strategy } \\
\text { a. The availability of human resources as a } \\
\text { companion can help in providing } \\
\text { understanding to the community and the } \\
\text { communication of community leaders is } \\
\text { followed up by providing an understanding } \\
\text { that this is a shared responsibility } \\
\text { b. The available budget will be optimally } \\
\text { utilized when it has been communicated and } \\
\text { the work plan is in place. }\end{array}$ & $\begin{array}{l}\text { WT Strategy } \\
\text { a. The capacity of KPM is not } \\
\text { yet optimal so it cannot } \\
\text { provide a proper } \\
\text { understanding to the } \\
\text { community that this is a shared } \\
\text { responsibility. } \\
\text { b. A less than optimal budget can } \\
\text { be used to provide an } \\
\text { understanding of stunting }\end{array}$ \\
\hline
\end{tabular}

Table- 8 shows that the analysis of internal factors consisting of strengths and weaknesses, as well as external factors consisting of opportunities and threats from the stunting management program resulted in four alternative strategic choices consisting of SO (strengths and opportunities), WO (weaknesses and opportunities), ST (strengths and threats) and WT (weaknesses and threats). Based on the analysis of internal and external factors, the selection of strategies and the SWOT matrix, there are opportunities that can run well by utilizing existing strengths, so the strategies obtained are:

1. Using the available budget for optimal stunting management;

2. Increasing the capacity of human resources can be through the support of the district government.

The strategy above is expected to be implemented by the Village Government assisted by Human Development Cadres in efforts to deal with stunting in Malutu Village. This is also supported by the District Government, Padang Batung Health Center and Posyandu Cadres. The involvement of the community in general and the village government in the implementation of empowerment in efforts to deal with stunting in Malutu Village will greatly assist and facilitate the implementation of this activity, both in disseminating information about stunting and forms of early stunting prevention.

\section{CONCLUSION}

The role of KPM in Malutu Village is not only to assist in posyandu activities but also to raise awareness about the meaning of stunting. However, in reality there are still problems faced by KPM in handling stunting. The not yet optimal function of cadres in educating the meaning of stunting and the dangers it causes is one of the problems faced by KPM. This causes a lack of public awareness about the dangers of stunting which will certainly hinder the suppression of the prevalence rate of stunting. In addition, the capacity building given the time is still limited so that field provision is not sufficient and the absence of further training to solve problems encountered in the field is also one of the obstacles in itself.

The strategy in community empowerment programs in efforts to deal with stunting in Malutu Village is the SO strategy. SO strategy is a strategy that is determined to get optimal effort. After knowing and 
taking advantage of the strengths, we can take full advantage of the opportunities that exist. Community empowerment strategies that can be implemented include using the available budget for optimal stunting handling, increasing the capacity of human resources through support from the district government; and establish communication between actors and create joint work plans in dealing with stunting.

\section{REFERENCES}

1. ACC/SCV. 1997. "3rd Report on The World Nutrition Situation”. Geneva. Diakses pada 22 Februari 2012 dari www.unscn.org

2. ACC/SCV. 2000. "4th Report on The World Nutrition Situation: Nutrition throughout the Life Cycle". Geneva. Diakses pada 25 Januari 2012 dari www.unscn.org

3. Bhutta, ZA, Ahmed, T., Black, RE. 2008. Maternal and Child Undernutrition 3: What Works? Interventions for Maternal andChild Undernutrition and Survival. Lancet 2008: 371: 417-40
4. Kementerian Desa Pembangunan Daerah Tertinggal dan Transmigrasi, 2017, Buku Saku Desa dalam Penanganan Stunting, Direktorat Jenderal Pembangunan dan Pemberdayaan Masyarakat Desa, Jakarta.

5. Kementerian Desa Pembangunan Daerah Tertinggal dan Transmigrasi, 2018, Pedoman Umum Kader Pembangunan Manusia, Direktorat Jenderal Pembangunan dan Pemberdayaan Masyarakat Desa, Jakarta.

6. Kementerian Desa Pembangunan Daerah Tertinggal dan Transmigrasi, 2018, Panduan Fasilitasi Konvergensi Pencegahan Stunting di Desa, Direktorat Jenderal Pembangunan dan Pemberdayaan Masyarakat Desa, Jakarta.

7. Moleong, Lexy. 2003. Metodologi Penelitian Kualitatif. PT Remaja Rasdakarya. Bandung.

8. Peraturan Presiden Nomor 59 Tahun 2017, Tentang Tujuan Pembangungan Berkelanjutan.

9. Semba, R. D. dan M. W. Bloem. 2001. Nutrition and Health in Developing Countries. New Jersey: Humana Press.

10. Sugiyono. 2012. Metode Penelitian Kombinasi (Mixed Methods). Alfabeta: Bandung 